\title{
E-Learning Technologies for Open Distance Learning Knowledge Acquisition in Management Accounting
}

\author{
Trust Kashora, Huibrecht M. van der Poll, \\ and John A. van der Poll \\ University of South Africa, Pretoria, Gauteng, South Africa
}

trustkash@yahoo.com, vdpolhm@unisa.ac.za, vdpolja@unisa.ac.za

\begin{abstract}
This research seeks to establish how e-Learning technologies may contribute towards knowledge construction for management accounting students at the University of South Africa, an ODL (Open and Distance Learning) institution, utilizing online education and e-Learning. Crucial to the knowledge construction process is to understand how students learn in order to determine a set of suitable learning strategies. E-learning, being a form of education conducted mostly over the Internet, networks or standalone computers refers to the use of electronic applications and processes for learning, and it includes the transfer of skills and knowledge over a distance. Studies have shown that generally there is poor usability of e-learning applications, sometimes due to inappropriate content and use of technologies. Cited factors are costs, poor or insufficient technology infrastructures or a lack of access to such infrastructures as well as a shortage of human resources.
\end{abstract}

Academic communities acknowledge the value of e-Learning software in management accounting education and educators should become more involved in the design and development of pedagogical software applications. Modern management accounting educators ought to know how to incorporate spreadsheet models, graphical images and video into the classroom and how to construct web pages for remote students. To this end the Institute of Management Accountants reported the top skills for its members, amongst others, as being computer and technology literate. As with many subject curricula, these topics generally do not appear in prescribed books for management accounting courses. The gap between ICTs and strategic decision-making processes within organizations ought to be addressed as well. We argue in this paper that e-Learning technologies have the potential to make a significant contribution in this regard.

Despite the advantages brought about by the use of ICTs, such technologies must not be detrimental to learning management accounting principles. One may find that students spend a significant amount of time learning to use the hardware and software systems instead.

Improved learning activities occur when such learning is embedded in "meaningful and authentic problem-solving activities"; hence our

Material published as part of this publication, either on-line or in print, is copyrighted by the Informing Science Institute. Permission to make digital or paper copy of part or all of these works for personal or classroom use is granted without fee provided that the copies are not made or distributed for profit or commercial advantage AND that copies 1) bear this notice in full and 2) give the full citation on the first page. It is permissible to abstract these works so long as credit is given. To copy in all other cases or to republish or to post on a server or to redistribute to lists requires specific permission and payment of a fee. Contact Publisher@InformingScience.org to request redistribution permission. approach strongly supports learning by doing, or experiential learning. To this end the use of learning scaffolds may be advantageous. Using scaffolding, students are given extensive support during the early stages of their learning, and such support is gradually reduced to facilitate independent learning. We suggest that course designers develop learning experiences whereby learners can 
construct their own interpretations and ideas, instead of just designing the traditional course content.

Some of the contributions of our research are that Management accounting could assume a new pedagogical identity within the e-learning technologies realm. The timeline towards such a pedagogical paradigm shift may also be shortened by critically examining how knowledge can best be constructed in an e-learning management accounting environment. A value-creating management accounting system, once incorporated into the organization could support strategic management decisions.

We also developed an analysis framework, using the above ideas and such framework will form the blueprint for an e-Learning framework in which, amongst others, the use of ICTs, learn by doing, course experiences and scaffolding will be incorporated.

Keywords: E-learning, framework, constructivism, open distance learning (ODL), open distance learner, pedagogy.

\section{Introduction}

The World Wide Web (WWW) originated roughly from 1991 onwards and by 1997, it started having a significant impact on the development of the Internet (Humphrey \& Lee, 2004). For example, in 1997 Alan Sangster conducted research into Web-based accounting education. His findings revealed a growing integration of the Web into accounting education. From these humble beginnings online accounting education continued to evolve and grew in tandem with prevailing technological advancements. The current developments in this area may contribute positively towards knowledge acquisition in management accounting for distance learners. This paper discusses how e-learning technologies may benefit the construction of knowledge in management accounting in the open distance learning environments.

\section{Background}

A common trend in the literature is that online learning helps learners to construct their own interpretations and ideas, a factor that suggests an improvement in the quality and quantity of learning (Bates, 2005). Therefore, the claim that e-learning technologies offer new possibilities for study and promote the quality of learning is often taken for granted. Hence, the extent to which information and communication technologies (ICTs) can promote knowledge, using constructivist approaches to learning in management accounting may need to be established.

\section{E-Learning: the Concept}

E-learning may be defined as a form of education via the Internet, networks or standalone computers. It includes the transfer of skills and knowledge (normally over a distance), and it refers to using electronic applications and processes to learn (Bates, 2005; Guri-Rosenblit, 2009).

Amongst others, e-learning processes may encompass:

- Web-based learning

- Computer-based learning

- Virtual classroom and

- Digital collaboration

E-learning content is delivered mostly via the Internet, intranet, extranet, audio or video tape, satellite TV, or CD-ROM. Therefore e-learning is centered in Information and Communication Technologies (ICTs). In this paper, e-learning is viewed as having this expanded meaning. 


\section{The Nature and Challenges of E-Learning}

Studies have shown that generally there is poor usability of e-learning applications, sometimes due to irrelevant content and inappropriate use of technologies (Bates, 2005; Goodfellow \& Lea, 2007; Ssemugabi \& de Villiers, 2010). Some cited contributory factors are poor or insufficient technology infrastructure or a lack of access to such infrastructures as well as a lack of human resources. Hidden costs in the form of support and maintenance of infrastructures related to the training of staff are other impediments.

Literature on learning and teaching suggest that learning takes place when it is embedded in "meaningful and authentic problem-solving activities" (Naidu, 2006; Schank, 2005:231). This approach is founded on the principles of learning by doing and experiencing tasks. The concept of learning by doing also called experiential learning is a pedagogical design, aimed at facilitating the learning process. The following alternative forms of learning by doing could be ideal in establishing a base for constructing knowledge systems:

- scenario-based learning

- goal-based learning

- problem-based learning

- case-based learning

- learning by designing

- role-play-based learning.

Related to the idea of experiential learning, Schank (2005) associates successful learning with constant practice: "Practice means endless repetition not just trying something once" (Schank, 2005). Therefore, when learning or performing a task, subsequent practicing of the concepts facilitates the learning process, while feedback and reflection usually follow. Scholars generally acknowledge that experience is the real teacher and course designers need to design experiences and not just courses. In this way, a platform for the construction of knowledge would be well suited.

Most online learning takes place on the ubiquitous platform of the World Wide Web now popularized as WWW dot something. The Web was not applied systematically to education until 1995, but the potential for an educational paradigm shift had already been recognized and acknowledged. What remained was to design new approaches to teaching that would fully utilize the advantages of e-learning technologies. Bates (2005), after some comprehensive research on Webbased learning, concluded that there was a long way to go before Web-based learning would become a pedagogical paradigm shift. The research proposed in this paper may well shorten the timeline towards such a paradigm shift by critically examining how knowledge can best be constructed in an e-learning management accounting environment.

\section{Perspectives of Management Accounting Education Online}

According to Orapin, Gray and Williams (2007), there is a scarcity of both empirical and descriptive accounting-based research especially in online education, hence the aim of this study to make a contribution towards filling such gap. Some findings on research conducted in the field of accounting reveal that accounting students were mostly practical in their approaches; they want to determine how a system works and how it will be useful to them; they prefer discovery-type inquiry and would find an interactive style as the preferred instructional method (Novin, Arjomand \& Jourdan, 2003; Calvert, Kurji \& Kurji, 2011; Kolb \& Kolb, 2008). The same findings further established that accounting students learn by doing, hence the need to allow them to work on problems and cases that evaluate alternatives and to arrive at answers logically. Understanding how students learn constitutes a crucial part of selecting suitable teaching strategies. 
Efforts to incorporate computers into accounting education have been around for some time, especially after the advent of the personal computer (PC). Cramer (1966) argued that the teacher alone could no longer manage large student numbers, but needed the aid of a computer in teaching. As a result, he pioneered some research work into the teaching of management accounting using an IBM 1410 computer. Early critics of the effect of computers in enhancing learning make reference to Clark \& Meyer's (1983) mere vehicles argument, that media in instruction can be compared to vehicles that deliver groceries but do not cause changes in the nutrition; instead, he suggested that media are mere vehicles that deliver information but do not influence student achievement in accounting. The American Accounting Association (AAA) (1985) committee studied the integration of microcomputers into a Financial Accounting Curriculum and concluded that computers could be part of accounting curricula. However, they noted that inappropriate use of computers may be detrimental to learning accounting principles especially if the student spends a significant amount of time learning to use the hardware and software instead of learning about accounting.

The growth in online programmes spans most disciplines in US Universities, though the number of accounting courses offered online is lower than the online offerings of other business disciplines. National publishers like Prentice Hall and Irwin McGraw Hill provide distance-learning services which include online support for accounting classes to all students and professors (Dosch, 2010). Evidence, on the contrary, suggests a growing gap between information technology (IT) skills demanded of management accountants and those provided by higher education. A full integration of IT into management accounting courses may well enhance a more effective management accountant practitioner, compared to one without such integration (Chandra, Cheh \& Kim, 2006). It is expected that e-learning technologies will bridge this gap for management accountants engaged in open distance learning. In Australia, candidates who studied for a management accounting and analysis module were able to choose to do this module via the Internet during the second term of 2010 (Dosch, 2010).

Pedagogical applications of software in accounting education can be traced to 1981, shortly after the IBM PC was introduced. This was the time that accounting researchers examined computer applications in accounting pedagogy (Lin \& Smith, 2006). Accounting educators also designed a variety of materials for teaching issues. The accounting academic communities acknowledge the pedagogical importance of such software in accounting education (Lin \& Smith, 2006). There is a need therefore, for accounting educators to be actively involved in the design and development of pedagogical software applications.

A large body of research on the utility of online learning and the advantages it provides in opening a range of instructional technologies exists. Some advantages of distance learning and benefits of online learning are (Burke, 1998; Pearson, 2010; Bates, 2005):

- Convenience

- Improved learning opportunities

- Self-paced learning

- Opportunities for collaboration

- Learn anywhere, anytime: ideal for professional training needs e.g. Chartered Accountants, Certified Management Accountants, etc.

- Cost savings through the elimination of travel expenses

- Ease of access to the latest information

- A less intimidating environment than a face-to-face one

- Can access rural locations as well as cut across geographical barriers, hence ability to network nationally and internationally

- Environmental friendly and less travel, leading to reduced pollution and costs. 
Many predictions about the effects of the new e-learning technologies on higher education were based on some erroneous assumptions; or simply did not happen. Thomas Edison predicted in 1922 that the motion picture would revolutionize education, while William Levenson predicted the same for radio in 1945. And to date, the introduction of ICTs into education has yet to revolutionize education (le Grange, 2004; Bates, 2005; Guri-Rosenblit, 2009). The impact of the new technologies on learning and teaching is still unclear, and open to much debate. Guri-Rosenblit (2009) suggests that assessing the effect of new technologies on higher education environments might only be possible after ten to twenty years from the current time. Guri-Rosenblit (2009:16) however, makes interesting observations relating to how the new technologies have affected either directly or indirectly the study process in academic settings. The affected areas are:

- academic administration and management

- organization of libraries

- research networks

- new fields of study and physical infrastructure of the study environments.

It is plausible that new technologies will affect the study processes in a variety of ways, some of which we cannot envisage now.

\section{Challenges in Management Accounting}

The teaching of management accounting started in the 1950s with a strong focus on decisionmaking processes as compared to the conventional cost accounting activities which had a focus on inventory valuation. Therefore, management accounting assumed its early identity guided by this focus (Maher, 2000).

Management accounting is about managing internal operations to optimize organizational performance through adding stakeholder value. The main difference between cost accounting and management accounting was that cost accounting texts dealt entirely with numbers whereas management accounting recognizes that humans use those numbers (Boer, 2000; Brewer, 2008).

Some of the specific challenges within the management accounting environment include (Maher, 2000):

- College leavers experience difficulty in finding a job as a management accountant.

- Management accountants have a labeling dilemma. This may be due to the fact that in business schools, the discipline is called "management accounting" while in the business world it is referred to as "corporate finance" or "financial consulting".

- Management accounting topics in practice differ from those in academia. However, it appears that research and practice have been the main drivers of the management accounting growth.

- The downsizing of the accounting function in organizations in general is a possible threat to the traditional role of accounting. The increased use of technology may be a contributory factor.

- Despite significant changes in the business environment, accounting curricula have remained largely unchanged (Siegel, Sorensen, Klammer \& Rightermeyer, 2010). The accounting curricula and the education of students need to reflect the changing dynamics of business environments.

Management accounting educators require students to work in groups, which tends to increase their ability to work in teams on the job. They require students to do presentations in order to improve their presentation skills. In management accounting, there is also a need to teach problemsolving skills and the organizational context in which economic activities are conducted (Maher, 2000). ODL institutions may face a severe challenge by requiring students to work in groups, 
since their students are usually not on campus and may be dispersed across continents. The spirit of the research proposed in this paper may therefore be of much value in overcoming this problem. Lastly is the need to close the gap between ICTs and strategic decision-making processes within organizations. E-learning technologies have the potential to make a significant contribution in this regard.

Dosch (2010) argues that a successful career as a management accountant requires (a) the ability to clearly and accurately complete financial analyses and (b) the ability to effectively communicate the results of financial analyses to upper management and cross-functionally within an organization. As with most other disciplines, a management accountant has to adapt to changing needs, viz, economies change, technologies change, professional organizations change and the subject matter of management accounting changes continually. Management accounting textbooks have changed from an emphasis of cost accounting and financial reporting to decision making and management control in response to the changes (Boer, 2000).

Boer (2000) notes that today's management accounting teacher must know how to incorporate spreadsheet models, graphical images and video into the classroom and how to construct Web pages for student references outside the classroom. Kavanagh and Drennan (2008) reported some of the top skills for accounting practices to be computer and technology literacy; and fluent and effective speaking and communication. However, currently these topics do not appear in management accounting textbooks. There is therefore an opportunity within the emerging e-learning technologies to redress these omissions.

Technology seems to be the primary driving force for future changes within management accounting (Maher, 2000). Technology is able to do what accountants used to do for their managers in the past. The computer has taken over the computational skills of the traditional accountant. A value-creating management accounting system might directly support decisions of managers as they work to implement strategies. The adoption and adaptation of e-learning technologies could provide a possible solution to some of these challenges.

\section{Evolving Technologies in Teaching}

The teacher has been at the center of learning from as far back as the time of Moses and Socrates (Bates, 2005). The teacher communicated knowledge directly to the learner; he or she was the center of knowledge and the learner was the recipient of such knowledge. After the invention of the printing press in the fourteenth century, printed books were used to disseminate knowledge. Teachers now complemented the print material as repositories of knowledge, and schools and colleges were founded to cater for the educational needs of a growing population. The Industrial Revolution reinforced these developments leading to a rapid expansion of schools and universities.

Research reveals that distance education can be traced as far back as the 1800s (Burke, 1998). The introduction of the postal service and to some extent the telephone stimulated the start of correspondence education (Bates, 2005). Educational radio programmes (around 1924) were followed by television educational programmes (in the 1950s). This picture is fast changing, driven by technological advancements with the Web becoming the new center of knowledge. Information technologies have recently been introduced into the larger society as well as into educational environments with often unpredictable effects and outcomes. The Web site, the cell phone, the iPod, the Webcam, Web 2.0 social networking sites such as Facebook and MySpace, Wikipedia (and wikis in general), blogs, twitter, YouTube, social tagging sites and cloud computing, are all recent phenomena. Each of these technologies triggered a new form of communication and social connection, and of information acquisition and sharing in society at large and higher education in particular (Rudestam \& Schoenholtz-Read, 2009). 
Besides the multimodal environments present in most universities, there is actually more writing today (Goodfellow \& Lea, 2007). The development of new and Web-based technologies has resulted in more writing and more reading, more diversity and more variety in textual practices. Print might well continue to be a major teaching medium due to its ease of accessibility and convenience, while writing remains the dominant mode for the production and maintenance of knowledge, even in e-learning contexts (Bates, 2005; Goodfellow \& Lea, 2007). However, printed material has a major limitation in that it can only carry text, pictures and illustrations but does not have the flexibility endowed in hypermedia. The flexibility of hypermedia has triggered new innovations for instructional content especially for online and distance learners. Web 2.0 tools are in the practice of harnessing collective intelligence (Rudestam \& Schoenholtz-Read, 2009). The Web supports some forms of social interaction which in turn have become established components of distance education. Web 2.0 technologies also have certain educational qualities: blogging, wikis, e-portfolios, and social networks allow learners to clarify concepts, establish meaningful links and relationships and to test their mental models. And as a public forum, the process of concept formation, refinement, application and revision will be transparent to student peers and teachers in a manner that could enhance knowledge construction.

Distance learning is defined as education in which teacher and student are physically separated during a significant part of the instruction (Burke, 1998). However, today's distance learning may be defined as education in which the student and instructor, while physically separated, are intellectually connected via technology. The increasing popularity of the Internet has seen a steady growth in distance education especially in the developed world. For instance, more than half of American colleges and universities offer distance-learning courses. There is some convergence between distance learning and e-learning in terms of pedagogy as evidenced by the increasing trend towards more online courses over fewer print-based courses (Bates, 2005; Rudestam \& Schoenholtz-Read, 2009). Therefore the evolution of technologies for distributed learning has been characterized by convergence. Stand-alone systems have converged into the Web, while modes of face-to-face and distance education have converged into blended learning. A number of distance universities offer their teaching fully online. Examples of some of these universities are the Open University of Catalonia in Spain, University of Phoenix in the USA and Maryland, University College Tec de Monterrey in Mexico and Athabasca University in Canada.

The following section postulates the need for a management accounting framework incorporating the ideas presented so far in this paper.

\section{The Need for an e-Learning Framework}

The successful implementation of e-learning technologies faces some challenges, hence the need for a framework that addresses the challenges below:

- Lack of visual signals, logical sequences, emotive cues and the need for social, cognitive and teaching presences,

- Lack of pedagogical tools to support online instructors,

- Lack of access to the technology infrastructure,

- Lack of human resource capacities,

- The lack of a definition of the purposes and functions of electronic media can be compared to putting technology at the forefront of pedagogy instead of the other way round,

- Lack of costs analyses of online courses, online study material and online assessments,

- Poor or insufficient technology infrastructure,

- Financial, environmental and ethical challenges relating to the disposal of outdated computers,

- Lack of measuring the success of online learning, 
- The lack of clearly defined problems of the new technologies in Universities and colleges (Guri-Rosenblit, 2009:52),

- The lack of building a learning environment that includes active, engaging learning activities that foster critical thinking skills, feedback, motivation and support for students learning from each other,

- "The lack of direct teacher - student and student - student communication has been the Achilles heel of distance education for centuries" (Guri-Rosenblit, 2009:93).

- Lack of learning scaffolds.

A learning scaffold is a mechanism whereby students are given extensive support during the early stages of their learning, and such support is gradually reduced to facilitate independent learning (Love \& Fry, 2006). Scaffolding enables learners to build on their existing knowledge or to develop new learning strategies, hence for deep understanding, higher education needs to adopt a more constructivist framework to enhance the learning experience (Laurillard, 2008). Since ICTs create an open kind of pedagogical space where learners and learning, teachers and teaching all adopt new identities, online instructors of management accounting need to provide a welldesigned learning scaffold that encourages independent and deep learning.

This research seeks to establish how e-learning technologies may contribute towards the construction of knowledge in management accounting. Popular learning theories ought to be reviewed and their relevance to e-learning contexts highlighted. The motivation for the investigation is guided by prolific theories like constructivism and cognitivism and the quest to establish whether the use of technology can promote learning that is in line with these theories. The constructivist approach is more student-centered, emphasizing skills that support independent and self-motivated learning (Guri-Rosenblit, 2009). Authorities argue that understanding is an outcome of interacting with information and ideas. The learner actively constructs knowledge by formulating ideas into words whilst others react and respond to these ideas (Harasim, Hitz, Teles \& Turoff, 1995).

Table 1 below presents an analysis of the literature discussed so far on the topic of e-learning related to management accounting. We synthesize a number of good suggestions, challenges, contributions which the suggestions may lead to and some further observations. 


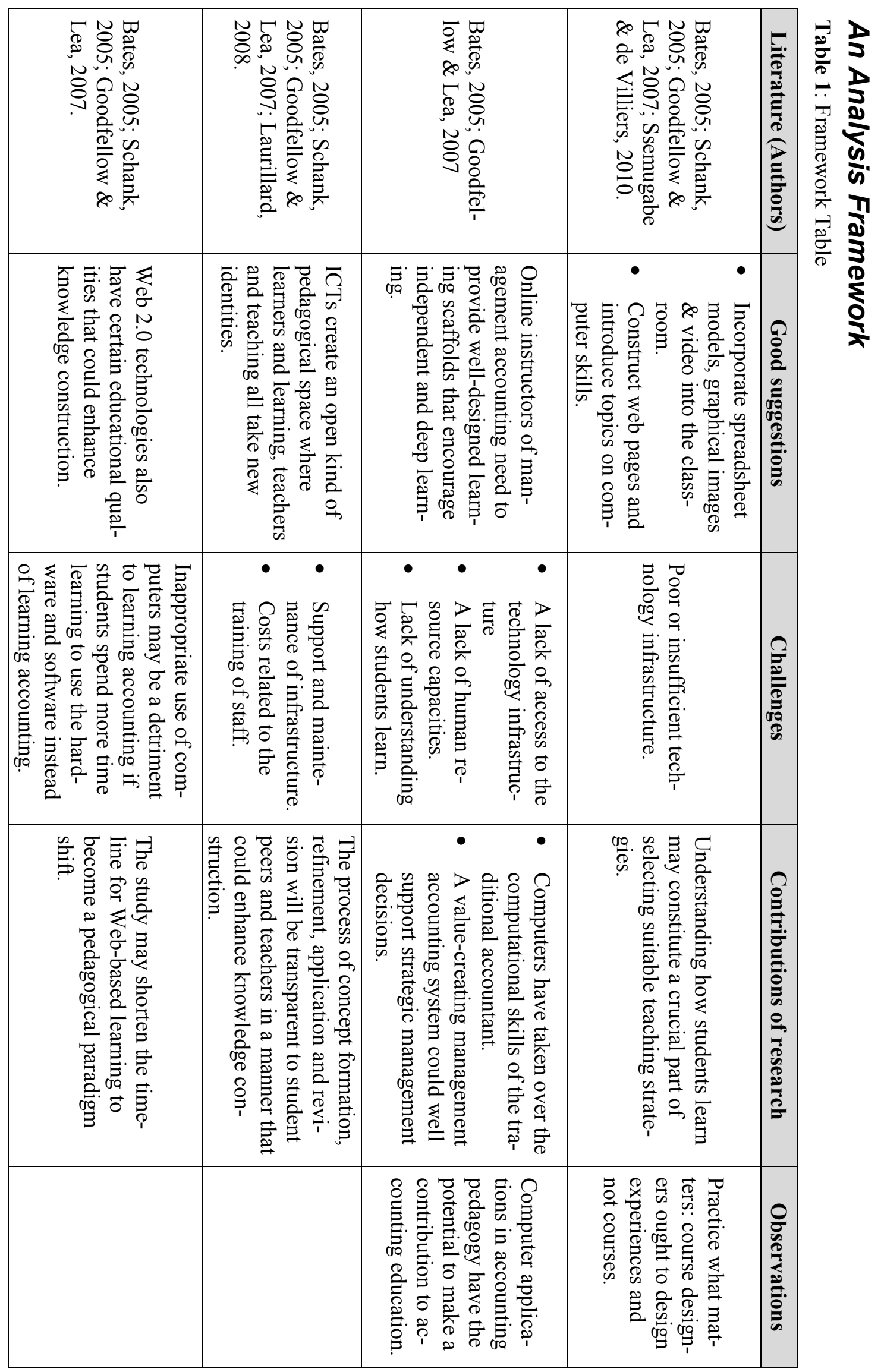


Our analysis framework is grouped into four areas:

- Suggestions synthesized from our research

- Challenges brought about by the suggestions

- Contributions of the research

- Observations of the research.

\section{Suggestions synthesized from our research}

It is suggested that spreadsheet models, graphical images and video be introduced into management accounting courses. Topics on computer skills and how to construct Web pages are further possibilities that have been identified. In other words, the modern management accountant has to be highly computer literate; therefore measures ought to be put in place to make this possible. It is also suggested that online instructors of management accounting need to provide a well-designed learning scaffold that encourages independent and deep learning. Since ICTs create an open kind of pedagogical space where learners and learning, teachers and teaching all take new identities, an opportunity seems to present itself for management accounting to assume a new identity within the e-learning technologies realm.

\section{Challenges of the research}

Most of the challenges translate to a need for monetary resources required to finance specific projects. Poor or insufficient technology infrastructure would need to be upgraded to a satisfactory level, whereas a total lack of access to the technology infrastructure would require more resources in terms of the funding involved. Costs related to the training of staff should help to alleviate the lack of human resource capacities while the challenge of inappropriate use of computers should become smaller as students become more comfortable on the experience curve.

\section{Contributions of the research}

Understanding how students learn may constitute a crucial part of selecting suitable teaching strategies and the type of pedagogy employed should take cognizance of this premise. Moreover, Web 2.0 technologies have certain educational qualities that could enhance knowledge construction. The qualities are embedded in blogging, wikis, e-portfolios and social networks that allow learners to clarify concepts, establish meaningful links and relationships and to be able to validate their mental models. Similarly a value-creating management accounting system might well support decisions of managers, once it has been incorporated into an organization.

\section{Observations of the research}

Schank (2005:14) writes "Practice means endless repetition not just trying something once". We believe this to be very true, therefore course designers are encouraged to design experiences and not just courses. It appears that computer applications in accounting pedagogy indeed have the potential to make a solid contribution to accounting education.

From the information synthesized in our work so far, we may next define a problem statement that embodies the needs identified above.

\section{Problem Statement}

Current developments in e-learning technologies can make a positive contribution towards knowledge acquisition in management accounting education for learners in an ODL (Open and Distance Learning) environment. We identify a 3-part motivation for this claim: 
- The rapid developments of e-learning technologies are such that disciplines like management accounting education could benefit from them.

- There is an increasing gap between the skills expected of management accounting practitioners in the field and those from the crop of management accountants being produced by institutions of higher learning. There is therefore an urgent need for e-learning technologies to remedy the situation.

- The dot net generation (techno generation) is growing up in a technological environment. Integrating e-learning technologies into their management accounting curricula would be a natural progression of their growth path.

This study sets to establish how the advent of modern technologies benefit teaching and learning in management accounting.

\section{Research Questions}

The research questions revolve around how the emerging e-learning technologies can best be integrated into a packaged solution for management accounting students in the open distance learning space. The main research question is:

- What pedagogical theories can be employed to enhance knowledge acquisition in management accounting education and what technology can be deployed to support that type of pedagogy?

The sub-questions associated with the main one are:

- What are the underlying pedagogical-, teaching- and learning theories for the concepts under consideration?

- Is a given course structured for online delivery in a way that allows for learning scaffolds, yet enabling the course to maintain its rigor?

- Are there mechanisms for preparing both learners and academic staff to use available technologies effectively enough?

The analysis framework would also have to consider peripheral questions around the concerns of how to incorporate e-learning technologies into the acquisition and construction of knowledge systems in management accounting education. The questions below are pertinent.

- Can web-based learning lead to a pedagogical paradigm shift? How can we achieve this paradigm shift in the context of management accounting?

- How can we facilitate management accounting learning so that students learn by doing? What activities do we need to include during the design stage of a management accounting course?

- How proficient are the students in the use of the relevant hardware and software? Do the students spend a significant amount of time learning to use the technology instead of (just) learning management accounting concepts and principles?

- Is there a full integration of IT into the management accounting courses? Are management accounting graduates well prepared for the demands and expectations of the business world?

- Do management accounting educators participate in the design and development of software and material used for teaching issues?

- Is it feasible to create an open kind of pedagogical space in the e-learning environment, where learners and learning, teachers and teaching and management accounting, all take on new identities? 


\section{Research Objectives}

This study seeks to achieve the following:

- To assess the usability of e-learning technologies in management accounting education.

- To explore the potential of ICTs in the development of pedagogical methodologies in management accounting.

- To develop an e-learning framework that would assist in overcoming barriers, using the analysis framework in Table 1 above.

\section{Assumptions}

The following assumptions will be operational in conducting this research.

- The levels of computer literacy for both lecturers and students will not impede the effective implementation of e-learning.

- All participants will have access to a computer/laptop which can connect to the Internet and the databases at the University of South Africa (UNISA).

- Wi-Fi and network connections will be stable and there will be no disturbances due to power or system failures.

- Some critical content in management accounting will be posted on the UNISA website.

- Participants will be thoroughly familiar with the myUnisa e-learning environment. (myUnisa is the university's online student support system.)

\section{Limitations}

The main limitations will be around issues of reliability and validity. Reliability concerns dependability or consistency of a measurement, while validity suggests truthfulness. For instance, a faulty measuring instrument will not give reliable measurements which can become a limitation to the study. There is therefore a need to validate the measuring instruments in the study so as to mitigate the limitations.

E-learning technologies is currently a topical area, therefore there is the chance of replication of some research results elsewhere.

The period of study is limited to the years 2012 and 2013. The study sample will be drawn from students currently registered in the Management Accounting course (ACN203S) at UNISA.

\section{Delineations}

This study has the following delineations:

- It is delineated to students in the ACN203S course at UNISA.

- It is delineated to lecturers at UNISA who teach ACN203S.

- The sample size will be calculated using a power analysis instrument.

\section{Significance of the Study}

This study is expected to be significant to users of the e-learning technologies, researchers and policy-makers of training and learning programmes.

- The study will survey the appropriateness of the myUnisa environment for e-learning and teaching and make recommendations which might benefit practice.

- This study may contribute to the knowledge base in the field of management accounting research. 
- The study will also test some pedagogical designs on e-learning and hence possibly contribute towards the utility of the designs.

- The study can act as a base for further studies on online management accounting education.

- The findings of the study may encourage policy-makers to implement e-learning methodologies in their institutions.

\section{Ethical Issues}

Ethical considerations will be taken into account when planning and conducting the research. This is consistent with what Creswell (2009) suggests that researchers should protect their research participants, develop a level of trust with participants, and promote the integrity of research and to guard against misconduct.

\section{Conclusion}

In this paper we motivated the need for a comprehensive e-learning approach to the teaching of and the learning of management accounting by students at higher education institutions. The institution to be targeted is the University of South Africa which specializes in ODL. Owing to its distance-teaching character, an e-learning approach would be most ideal.

A number of requirements and suggestions were identified from the literature discussed in this paper and from these analyses some challenges and additional observations were presented in Table 1 which represents our analysis framework. Such framework could serve as the starting point for the development of an e-learning framework for teaching students management accounting.

The research questions, objectives, assumptions, etc. were identified and future research will be guided according to these. Once the e-learning framework has been developed, it will be validated through a number of empirical studies performed on the module ACN203S at UNISA.

\section{References}

AAA. (1985) Committee on Integrating the Computer into the Managerial/Cost Curriculum, Integrating the Computer into the Managerial/Cost Curriculum: A Resource Manual. Sarasota.3

Bates, A. W. (2005). Technology, e-learning and distance education. Routledge: New York.

Boer, G. B. (2000). Management accounting education: Yesterday, today and tomorrow. Issues in Accounting Education, 15(2), 313-314.

Brewer, P. C. (2008). Redefining management accounting. Strategic Finance, 89(9), 27-34.

Burke, J., (1998). Educational focus: The Internet highway. New Accountant, 14(1), 26-31.

Calvert, V., Kurji, R., \& Kurji, S. (2011). Service learning for accounting students: What's the faculty role? Research in Higher Education Journal, March, 1-11.

Chandra, A., Cheh, J. J., \& Kim, I. W. (2006). Do we teach enough IT skills in management accounting courses? Management Accounting Quarterly, 8(1), 49-54.

Clark, R. C., \& Mayer, R. E. (2007). E-learning and the science of instruction: Proven guidelines for consumers and designers of multimedia learning. CA: Pfeiffer.

Cramer, J. (1966). Management accounting via computer assisted instruction. National Association of Accountants. NAA Management Accounting (pre-1986), 47(5), ABI/INFORM GLOBAL.

Creswell, J. W. (2009). Research design: Qualitative, quantitative, and mixed methods approaches. Los Angeles: Sage Publications Inc. 
Dosch, J. (2010). Teaching management accounting online. Cost Management, 24(2), 44-48.

Goodfellow, R., \& Lea, M. R. (2007). Challenging e-learning in the university: A literacies perspective (Society for Research Into Higher Education). New York: McGraw Hill.

Guri-Rosenblit, S. (2009). Digital technologies in higher education: Sweeping expectations and actual effects. New York: Nova Science Publishers Inc.

Harasim, L., Hiltz, R., Teles, L., \& Turoff, M. (1995). Learning networks: A field guide to teaching and learning online. Cambridge: MIT Press.

Lee, B., \& Humphrey, C. (2006). More than a numbers game: Qualitative research in accounting. Management Decision, 44(2), 180 - 197.

Kavanagh, M. H., \& Drennan, L.. (2008). What skills and attributes does an accounting graduate need? Evidence from student perceptions and employer expectations. Accounting and Finance, 48(2), 279300.

Kolb, A. Y., \& Kolb, D. A. (2008). Experiential learning theory: A dynamic, holistic approach to management learning, education and development. In S. J. Armstrong \& C. Fukami (Eds.), Handbook of management learning, education and development. London: Sage.

Laurillard, D. (2008). Rethinking university teaching: A framework for the effective use of learning technologies. New York: Routledge Falmer.

Le Grange, L. (2010) E-learning: some critical thoughts. South African Journal of Higher Education, 18(1), 87-97.

Lin, P. C. \& Smith, L. M. (2006). Using a web-based accounting system for teaching accounting system design and implementation. Journal of Information Systems, 20(2), 65-79.

Love, N., \& Fry, N., (2006). Accounting students' perceptions of a virtual learning environment: Springboard or safety net? Accounting Education, 15(2), 151-166.

Maher, M. W. (2000). Management accounting education at the millennium. Issues in Accounting Education, 15(2), 335-346.

Naidu, S. (2006). E-learning; A guidebook of principles, procedures and practices. CEMCA: New Delhi.

Novin, A. M., Arjomand, L. H., \& Jourdan, L. (2003). An investigation into the preferred learning styles of accounting, management, marketing, and general business majors. Teaching and Learning, 18(1), 2431.

Orapin, D., Gray, D., \& Williams, M. (2007). Transactional distance theory applied when designing international accounting online courses.

Pearson, C. (2010). The benefits of online learning. Charter. Sydney, 81(3), 52.

Rudestam, K. E., \& Schoenholtz-Read, J. (2009). Handbook of online learning (2nd ed.). Los Angeles: Sage.

Schank, R. C. (2005). Lessons in learning, e-learning and training. San Francisco: Pfeiffer.

Siegel, G., Sorensen, J. E., Klammer, T., \& Rightermeyer, S. B. (2010). The ongoing preparation gap in management accounting. accounting education: A guide for change. Management Accounting Quarterly, 11(4), 29-39.

Ssemugabi, S., \& de Villiers, M. R. (2010). Effectiveness of heuristic evaluation in usability evaluation of e-learning applications in higher education. South African Computer Journal, 45, 26-39. 


\section{Biographies}
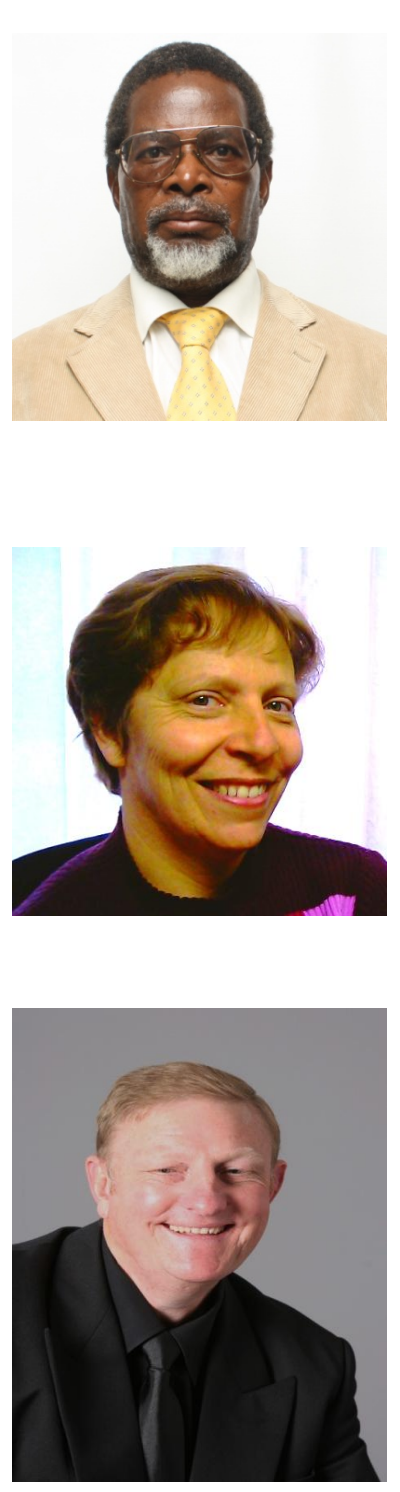

Trust Kashora has obtained his MCom from the University of South Africa 2006. He is currently a DCom student at the University of South Africa with promoters Prof. HM van der Poll and Prof JA van der Poll.

Huibrecht Margaretha van der Poll obtained her MCom degree in 2004 and her DCom in 2007 at the University of Pretoria. She is currently an Associate Professor in the Department of Management Accounting at the University of South Africa where she supervises a number of MPhil and PhD students. Her current research interest is in the field of business sizing and performance metrics at the micro and the macro level of companies. She has published widely and has delivered many papers at different National and International Conferences.

John Andrew van der Poll obtained his $\mathrm{PhD}$ in Computer Science at the University of South Africa (Unisa) in 2000. He is currently a Professor in the School of Computing at Unisa where he teaches Formal Program Verification, Software Specification Techniques, IT Management and Research Methodologies. His research interests are in Formal Specification Techniques, Automated Reasoning and Combining formal and semi-formal specification techniques. He supervises $\mathrm{MSc}$ and $\mathrm{PhD}$ students in these areas and is involved in a project aimed at determining the impact of Formal Methods in industry. 